\title{
THE INHIBITING FACTORS IN THE IMPLEMENTATION OF WOMEN AND CHILDREN PROTECTION UNIT'S ROLESS IN LAW ENFORCEMENT OF IMMORAL CRIMINAL ACT COMMITTED BY THE CLOSEST ADULTS TO MINORS IN THE JURISDICTION OF KEPAHIANG POLICE RESORT
}

\author{
By : \\ Davinsi Josie Sidabutar, Lidia Br Karo, Herlambang
}

\begin{abstract}
The increase in violence committed by parents and the closest adults to children brings a new concept that must be understood together where violence against children is not only a trivial matter and the private sphere, but has become the state and the public problem. Based on the facts and data that showed the rampant violence against children that often occurs in the area of Kepahiang Regency, namely, violence committed by parents and the closest adults to children, it becomes necessary for the efforts to protect children to be maximized. The protection efforts must be carried out by the police, especially by the Women and Children Service Unit. The Women and Children Service Unit also has main tasks contained in Article 3 of KAPOLRI Regulation Number 10 of 2007 concerning the Organization and Work Procedures of the Women and Children Service Unit within the Indonesian National Police environment. This study was conducted to obtain an overview, to understand and to analyze the factors inhibiting the implementation of the roles of Women and Children Protection Unit in law enforcement of immorality criminal acts committed by the closest adult to minors in the jurisdiction of Kepahiang Police Resort. The method applied in this study was an empirical juridical approach with qualitative analysis. The result of the study stated that the inhibiting factors in the implementation of the roles of Women and Children Protection Unit in law enforcement of immoral criminal acts committed by the closest adults to minors in the jurisdiction of Kepahiang Police Resort arose from internal and external factors.
\end{abstract}

Keywords: Inhibiting Factors, the Roles of Women and Children Protection Unit, Immorality Criminal Acts Committed By the Closest Adult to Minors 


\section{A. INTRODUCTION}

\section{Research Background}

Violence can be interpreted as a hard matter or the actions of a person or group of people who cause injury or death to others and cause physical damage to others. ${ }^{1}$ Lately sexual violence against children committed by the closest adults who are supposed to protect and look after children is increasing. Based on national data prior to 2018 according to National Women Commission, the rate of sexual violence that befell women was still high. In 2014, there were 4,475 cases recorded, in 2015 there were 6,499 cases and in 2016 there were 5,785 cases. $^{2}$

Immoral offense against children committed by the closest people which occurs nationally including in Bengkulu province, also occurs in Kepahiang Regency. Kepahiang Regency which is one of

\footnotetext{
${ }^{1}$ WJS Poerwadarminta, Kamus Umum Bahasa Indonesia, P.N Balai Pustaka, Jakarta, 1990, p.425

${ }^{2}$ https://Www.Rappler.Com/Indonesia/News/ 189514-Indonesia- Experiencing-EquencyViolence- Sexual Accessed on June 15, 2019 at 20:00 West Indonesian Time
}

the Regencies in Bengkulu Province. According to data compiled from the Police Department in 2018 there were 128 immoral cases occurred in Bengkulu Province including 14 cases occurred in North Bengkulu Regency Police Resort, 9 cases in Seluma Regency Police Resort, 4 cases occurred in South Bengkulu Police Resort, 25 cases occurred in Kepahiang Police Resort, 10 cases occurred in Rejang Lebong Police Resort and Lebong Police Resort, 6 cases occurred in Kaur Police Resort, 14 cases occurred in Mukomuko Regency Police Resort, whereas for Bengkulu City handled by Bengkulu Regional Police there were 25 cases handled by Bengkulu Police Resort and Bengkulu Regional Police handled as many as 8 cases. Based on these data, it could be seen that Kepahiang Regency was one of the regencies with a high level of immoral criminal acts. ${ }^{3}$ Based on the data that the writer obtained from the Kepahiang Regency Police Resort,

${ }^{3}$ www.rakyatbengkuluonline.com Accessed on June 15, 2019 at 20:00 West Indonesian Time 
it can be seen that there was an increase in immoral criminal acts against children in Kepahiang Regency from 2017 to mid-2019.

Based on Article 6 Paragraph (3) of KAPOLRI Regulation No. 10 of 2007 concerning the Organization and Work Procedures of Women and Children Service Unit (hereinafter will be referred as PPA Unit as it is used in Indonesian abbreviation) within the Indonesian National Police environment. The Women and Children Service Unit also has the main tasks contained in Article 3 of KAPOLRI Regulation No. 10 of 2007 concerning the Organization and Work Procedure of Women and Children Service Unit (PPA Unit) within the Indonesian National Police environment, it is stated that the main task of PPA Unit in general is:

"The PPA Unit is tasked with providing services, in the form of protection of women and children who are victims of crime and law enforcement of the perpetrators."

Based on the main tasks of the PPA Unit, the PPA Unit is one of the institutions responsible for the enforcement of the law, the PPA Unit is required to participate in supporting the realization and protection of the crime of violence against children in which this is supported by regulations that have been approved by the government. Law Number 23 of 2002 which was updated with Law Number 35 of 2014 concerning Amendments to Law Number 23 of 2002 concerning Children Protection and Law No. 23 of 2004 concerning the Elimination of Domestic Violence. Through these regulations, it is expected that the roles of the Women and Children Protection Unit in law enforcement, especially in the criminal act of immorality by the closest adult to minors can run well, in the midst of the rise and increasing cases of immoral acts committed by the closest adults against minors, especially those committed by the closest people. The increase in violence committed by parents and their closest adults to children brings a new concept that must be understood together where violence against children is not only a trivial matter and the private sphere but has become a problem of the state and problem. Based on the above background, the writer was 
ultimately interested in conducting this research. This will be further compiled in a journal entitled: "The Inhibiting Factors in The Implementation of Women and Children Protection Unit's Roles in Law Enforcement of Immoral Criminal Act Committed by the Closest Adults to Minors in the Jurisdiction of Kepahiang Police Resort".

\section{Identification of Problem}

What were the obstacles to the implementation of Women and Children Protection Unit's roles in law enforcement of immoral criminal act committed by the closest adults to minors in the jurisdiction of Kepahiang Police Resort?

\section{B. RESEARCH METHODS}

The method used in this study was a qualitative research with an empirical legal approach. Qualitative research is research that uses a holistic approach, which is an approach that requires a variety of information to be analyzed, so that certain aspects of human attitudes can be understood. ${ }^{4}$

\footnotetext{
${ }^{4}$ Sirman Dahwal, Pelaksanaan Perkawinan Beda
}

According to Abdulkadir Muhamad, empirical legal research is legal research of which the object of study includes provisions regarding the application or implementation of normative legal provisions (codification, law or contract) in action/in abstracto in every legal event that occurs in society (in concreto). ${ }^{5}$ Research location was located in the Kepahiang PPA Unit with data collection were carried out through documentation studies and interviews to answer the issues raised, and compiled into scientific papers in the form of journal.

\section{RESULTS AND DISCUSSION}

The Inhibiting Factors in The Implementation of Women and Children Protection Unit's Roles in Law Enforcement of Immoral Criminal Act Committed by the Closest Adults to Minors in the Jurisdiction of Kepahiang Police Resort

Law enforcement is an effort to realize legal ideas and concepts that people expect to become reality. Law

Agama (Study of Various Cases in Indonesia in the Period of 1986- 2010), Journal of Bengkoelen Justice Law, Post Graduate Law Program vol.2.No.2.2012, pp.464-465.

\footnotetext{
${ }^{5}$ Abdulkadir Muhamad, 2004, Hukum dan Penelitian HUkum, Citra Aditya Bakti, Bandung, p. 134
} 
enforcement is a process that involves many things. ${ }^{6}$ Law enforcement is an effort to bring the ideas of justice, legal certainty and social benefits into reality. So law enforcement is essentially the process of embodying ideas. Law enforcement is the process of carrying out efforts or the actual functioning of legal norms as guidelines for those who run legal relations in the life of society and the state. ${ }^{7}$

Joseph Goldstein cited by Dellyana, Shant distinguishes criminal law enforcement into three parts namely:

1) Total enforcement, namely the scope of criminal law enforcement as formulated by substantive criminal law (substantive law of crime). This total criminal law enforcement is not possible because law enforcers are strictly limited by criminal procedural law which includes rules for arrest, detention, search, confiscation and preliminary examination. Besides, it may be possible for substantive criminal law itself to provide restrictions. For example, complaints are needed first as a condition for prosecution in offenses for complaints (klacht

\footnotetext{
${ }^{6}$ Dellyana, Shant. Konsep Penegakan Hukum, Liberty, Yogyakarta, 1988, p. 32

7 Ibid, p. 37
}

delicten). This limited scope is called the area of no enforcement.

2) Full enforcement, after the total scope of criminal law enforcement is reduced by the area of no enforcement in law enforcement, law enforcers are expected to maximize law enforcement.

3) Actual enforcement, according to Joseph Goldstein, full enforcement is considered not a realistic expectation, because there are limitations in terms of time, personnel, investigation tools, funds and so on, all of which lead to the necessity of discretion, and the rest is what is called the actual enforcement. $^{8}$

According to Satjipto Raharjo, law enforcement is a process to realize the legal desires (ie the thoughts of the legislature were formulated in legal regulations) become reality. ${ }^{9}$ The law maintains that a relationship in society does not occur vigilantly (eigenrichting). Law enforcement in carrying out the roles of an organization or unit in this case specifically the protection of women and children units is interrelated. The roles of the Women and Children Protection Unit are

\footnotetext{
${ }^{8}$ Ibid, p. 39

${ }^{9}$ Satjipto Raharjo, Penegakan Hukum, Genta Publishing, Yogyakarta, 2009, p. 24
} 
divided into several sections including:

1) Preventive protection is carried out through counseling and outreach activities for the protection of women and children of the PPA Unit.

2) Repressive protection is carried out by the PPA Unit by providing Women and Children Integrated Service Center (P2TPA in Indonesian abbreviation), Women Crisis Center (WCC), Social Service, and Women and Community Empowerment Office (KPMP in Indonesian abbreviation).

3) Monitoring the health condition of the victim and request a visum et repertum, providing counseling, placing the victim in a safe house (shelter).

4) Notifying the progress of case handling, and ensuring the safety of victims who withdraw their complaints. The protection is in accordance with the provisions of Article 17 of the Elimination of Domestic Violence Act and Article 10 of Perkap Number 3 of 2008. However, there is a right that is not obtained by the victim, namely obtaining a protection order from the court as regulated in Article 16 paragraph (3) of the Elimination of Domestic Violence Act.

The roles of Women and Children Protection Unit in law enforcement of immoral criminal act committed by the closest adults to minors in the jurisdiction of Kepahiang Police Resort which includes examining, assisting and law enforcement are not always going well. It occurs due to several actors that occur both within the internal and the external. According to the Head of PPA Unit, Ipda Reka, factors inhibiting the implementation of the roles of Women and Children Protection Unit in law enforcement of immoral criminal act committed by the closest adults to minors in the jurisdiction of Kepahiang Police Resort includes: ${ }^{10}$

a. Funding factor, is a crucial factor that becomes an obstacle in the implementation of the roles of Women and Children Protection Unit in law enforcement of immoral criminal act committed by the closest adults to minors in the

${ }^{10}$ The data was obtained based on the results of the researchers' interview with Kepahiang PPA Police Unit conducted by researchers on November 20,2019 at $13.00 \mathrm{WIB}$ 
jurisdiction of Kepahiang Police Resort. The lack of funds prevents the PPA unit from being able to carry out its roles in prevention, that is, socializing prevention that must be carried out by families and children so that these criminal acts do not occur.

b. HR factor, is an obstacle to the implementation of the roles of Women and Children Protection Unit in law enforcement of immoral criminal act committed by the closest adults to minors in the jurisdiction of Kepahiang Police Resort. Where the number of policewomen in the Kepahiang Police Resort and those in the PPA Unit only amounts to 5 (five) people so that for the reception of reports in front office it is handled by male police. This sometimes makes the victims uncomfortable, and in terms of quality where PPA members who received training are still unequal.

c. The mindset factor also becomes an obstacle to the implementation of the roles of Women and Children Protection Unit in law enforcement of immoral criminal act committed by the closest adults to minors in the jurisdiction of Kepahiang Police Resort. Most people assume that if a victim reports an incident then the victim and family are considered to have opened their own disgrace.

d. Lack of coordination of law enforcement officers can be seen from the decision of the panel of judges under the prosecutor's demands and the hope of the investigators. This makes the victim feel disappointed with the decision that is considered not comparable to the actions committed by the perpetrators.

e. Lack of facilities as well as support from the regional government, also become an obstacle in the implementation of the roles of Women and Children Protection Unit in law enforcement of immoral criminal act committed by the closest adults to minors in the jurisdiction of Kepahiang Police Resort.

f. No written collaboration as stated in KAPOLRI Regulation No. 10 of 2007 Article 4.

g. Sanctions for perpetrators are still 
considered too light and unbalanced. In addition to the aforementioned factors, according to three families of victims of immoral acts, the reasons why they have recently dared to report this incident to the police are as follows:

a According to IT, the mother of the victim PGY said that the witness have just learned of the rape incident from the confession of her child and the victim's sister, besides that the witness was initially afraid to report because she was threatened by the perpetrator and was afraid of public ridicule against her and her future child because they were considered "dirty".

b. According to TN, the mother of the victim DY revealed that there were many reasons why she did not report what had happened to her child and allowed her child as a victim accompanied by her aunt to report. this is because they are ashamed of their neighbors and are considered despicable, other than that they are afraid to report in case it costed money.

c. $\mathrm{YN}$, the mother of the victim of immoral crime said that her assumption so far for victims who report must be blamed by others and in being snapped so that it would be pitiful for her children who have become victims, in addition they were afraid to spend money because they did not have money, other than that there were other considerations why the incident of immorality that befell her child was not reported.

The confession of the victim's family is also recognized by the customary chief of the Kepahiang village of Kepahiang Regency who stated that there were many factors why law enforcement against perpetrators of immoral crimes committed by the closest adult to children was only minimally reported and processed legally. As for the factors were: the victims' families still consider the family relationships and relationships of victims and perpetrators; the victims were more silent and scared because they felt ashamed; victims' families often casted out victims so that victims felt depressed; lack of knowledge of the law so that many people think that it was useless to report the perpetrators because ultimately victims were also blamed; there were still paradigms and negative thoughts that develop in the community about victims. 
According to Hanafi as a customary apparatus in the Sengkuang village of Kepahiang Regency stated that traditionally there were sanctions imposed on the perpetrators but not infrequently these traditional sanctions would also impact on the families of the victims by expelling the perpetrators and their families from the village. This was also what might have caused the victims' families to be more silent about the immoral acts that occurred. Based on the foregoing, it could be seen that the inhibiting factors of the implementation of the roles of Women and Children Protection Unit in law enforcement of immoral criminal act committed by the closest adults to minors in the jurisdiction of Kepahiang Police Resort arose from:

a. Internal factors of the protection unit for women and children in Kepahiang Police Resort, namely, lack of funds to carry out socialization activities and assistance to victims after the incident. Socialization activities are activities that should be important because they are prevention. However, based on the PPA's acknowledgment, the funds were insufficient, so that the socialization activities that should have been carried out maximally were not optimal, the lack of human resources was one of the internal inhibiting factors where the lack of human resources, namely the small number of policewomen, resulted in the handling process taking a little longer.

b. External factors from the protection unit of women and children Kepahiang Police Resort, namely the mindset of the community who still think that the victim was despicable and was guilty of immoral cases, lack of knowledge from the public about the law enforcement process so that it still raised stigma, lack of support from the government, sanctions or punishment that were still light.

The inhibiting factor in the implementation of the roles of Women and Children Protection Unit in law enforcement of immoral criminal act committed by the closest adults to minors in the jurisdiction of Kepahiang Police Resort arised from internal factors of the PPA unit itself and from external or external actors. This hampers the process of law enforcement that is good and right that 
should be carried out in order to achieve the maximum goal in protecting the child victims of immoral acts. Based on this description when analyzed using the Roles theory, there was a role implementation that was not going well, namely the roles of the government that has not been well conducted so that this results in the law enforcement process running not optimally and not providing full and complete legal protection as it should be. Moreover, if analyzed by using Chance theory by Lacassagne, it is stated that the public who give chance to do bad deeds in which they became ignorant with their environment and take part in judging the victims also becomes the inhibiting factor in the implementation of the roles of Women and Children Protection Unit in law enforcement of immoral criminal act committed by the closest adults to minors in the jurisdiction of Kepahiang Police Resort.

According to the writer's analysis the inhibiting factors of the implementation of the roles of Women and Children Protection Unit in law enforcement of immoral criminal act committed by the closest adults to minors in the jurisdiction of Kepahiang Police Resort when viewed from the characteristics of law enforcement towards the direction of development, it has not yet reached the characteristics of law enforcement towards the direction of development in which according to Satjipto Raharjo, the characteristics of law enforcement towards the direction of legal development, namely:

1) Having environmental awareness, it means that actions in law enforcement should link to processes that take place in society, such as economics, politics and so on;

2) Recognizing its position and qualifications as a body that must participate in driving changes;

3) Law enforcement will be more involved in the problem of decision-making than just being an executing body.

According to the writer's analysis the inhibiting factors of the implementation of the roles of Women and Children Protection Unit in law enforcement of immoral criminal act committed by the closest adults to minors in the jurisdiction of Kepahiang Police Resort when viewed from the theory of law enforcement by Satjipto Raharjo law enforcement is essentially 
the enforcement of ideas or concepts about justice, truth, social benefits, and so on. Then according to the writer's analysis law enforcement of immoral crime by the closest adult to a minor in the jurisdiction of the Kepahiang Police Resort has not yet realized ideas and concepts about justice, truth, social benefits, become reality. This was due to in the enforcement process in the stage of giving punishment has not given social benefit and has not resembled justice which could be seen from court decision which unbalanced with the suffer that must be felt by the victims all their lives.

In addition to analyzing by using Satjipto Raharjo law enforcement theory, the implementation of the roles of Women and Children Protection Unit in law enforcement of immoral criminal act committed by the closest adults to minors in the jurisdiction of Kepahiang Police Resort according to Joseph Goldstein as quoted by Dellyana Shant distinguishes criminal law enforcement into 3 sections, then according to the writer's analysis the implementation of the roles of Women and Children Protection Unit in law enforcement of immoral criminal act committed by the closest adults to minors in the jurisdiction of Kepahiang Police Resort was not in accordance with the theories below:

1) Full enforcement, after the total scope of criminal law enforcement is reduced by the area of no enforcement in law enforcement, law enforcers are expected to maximize law enforcement;

According to the writer's analysis, Full enforcement theory cannot run well and law enforcers cannot apply the law to the maximum. It is influenced by internal and external factors as mentioned earlier.

2) Actual enforcement, according to Joseph Goldstein, full enforcement is considered not a realistic expectation, because of limitations in the form of time, personnel, investigation tools, funds and so on, all of which lead to the necessity of discretion, and the rest is what is called actual enforcement.

According to the writer's analysis, Joseph Goldstein's view of full enforcement was in accordance with the facts in the field where the limited time, personnel and mindset factors become an inhibiting factor in the implementation of the roles of Women and Children Protection Unit in law enforcement of immoral criminal act committed by the closest adults to minors in the 
jurisdiction of Kepahiang Police Resort.

Based on the foregoing it can be concluded that the inhibiting factors of the implementation of the roles of the protection unit of women and children in law enforcement of criminal acts of immorality by the closest adult to minors in the jurisdiction of the Kepahiang Police Station arise from factors:

a. Internal factors from the women and children protection unit in Kepahiang Police Resort were:

1) The factor of lack of funds to carry out socialization activities and assistance to victims after the incident. Socialization activities are activities that should be important because they are prevention. However, based on the PPA's acknowledgment, the funds were insufficient, so that the socialization activities that should have been carried out maximally were not optimal.

2) The HR factor is one of the internal inhibiting factors where the quantity of HR was lacking, in which the small number of policewomen resulting in the handling process took a little longer, moreover the quantity of HR also became problem where PPA members who received training were still unequal.

3) There was no written collaboration between the Kepahiang Regency PPA Unit with the Kepahiang Government and related agencies. This greatly affected the handling of victims' recovery after the incident.

b. External factors included the mindset of the people who still think that the victims were despicable and were also guilty of the occurred immoral cases, lack of knowledge from the public about the law enforcement process so that it still raised stigma, lack of support from the government, criminal sanctions applied that were still light.

The aforementioned factors result in law enforcement not being maximized and not yet reflecting the characteristics of law enforcement towards development because there was still a lack of support from the central government and regional governments for law enforcement 
against immoral criminal acts committed by adults to children.

\section{CLOSING}

\section{Conclusion}

The inhibiting factors to the implementation of the roles of Women and Children Protection Unit in law enforcement of immoral criminal act committed by the closest adults to minors in the jurisdiction of Kepahiang Police Resort arose from:

1) Internal factors from the women and children protection unit in Kepahiang Police Resort, namely, the lack of funds to carry out socialization activities and assistance to victims after the incident, HR factor is one of the internal inhibiting factors where the quantity of HR was lacking, in which the small number of policewomen resulting in the handling process took a little longer, moreover the quantity of HR who received training were still lacking, there was no written collaboration between the Kepahiang Regency PPA Unit with the Kepahiang Government and related agencies. This greatly affected the handling of victims' recovery after the incident.

a. External factors from the women and children protection unit in Kepahiang Police Resort included the mindset of the people who still think that the victims were despicable and were also guilty of the occurred immoral cases, lack of knowledge from the public about the law enforcement process so that it still raised stigma, lack of support from the government, criminal sanctions applied that were still light.

\section{Suggestion}

Based on those conclusions, the researcher conveyed his suggestions as follows:

1. In the future both the parents and the environment should be more caring and sensitive and take care of their children and give them knowledge about the importance of protecting sensitive areas from others both close and distant people;

2. POLRI should improve the quality and quantity of human resources in areas, especially in 
Kepahiang, so that the handling of law enforcement cases of immoral crime can be handled properly and the roles of PPA can run more optimally. In addition, law enforcement officials should work together in seeking law enforcement for immoral cases committed by closest adults to children.

3. The government and the legislature should make and ratify new regulations that can give a deterrent effect to the perpetrators, and the customary sanctions should be given only to the perpetrators not to the victims and their families so that law enforcement will more optimal.

\section{REFERENCES}

Abdulkadir Muhamad, 2004, Hukum dan Penelitian HUkum, Citra Aditya Bakti, Bandung.

Dellyana, Shant. Konsep Penegakan Hukum, Liberty, Yogyakarta, 1988.

Satjipto Raharjo, Penegakan Hukum, Genta Publishing, Yogyakarta, 2009.

Sirman Dahwal, Pelaksanaan Perkawinan Beda Agama (Study of Various Cases in Indonesia in the Period of 19862010), Journal of Bengkoelen Justice Law, Post Graduate Law Program vol.2.No.2.2012.
WJS Poerwadarminta, Kamus Umum Bahasa Indonesia, P.N Balai Pustaka, Jakarta, 1990.

https://Www.Rappler.Com/Indonesia/News/ 189514-Indonesia- ExperiencingEquency- Violence- Sexual Accessed on June 15, 2019 at 20:00 West Indonesian Time

www.rakyatbengkuluonline.com Accessed on June 15, 2019 at 20:00 West Indonesian Time 
